University of Louisville

ThinkIR: The University of Louisville's Institutional Repository

\title{
From colonialism to neoliberalism : modernity and the state production of a Bedouin-Transjordanian national identity.
}

Amanda M. Yee

University of Louisville

Follow this and additional works at: https://ir.library.louisville.edu/honors

Part of the Political Science Commons

\section{Recommended Citation}

Yee, Amanda M., "From colonialism to neoliberalism : modernity and the state production of a BedouinTransjordanian national identity." (2013). College of Arts \& Sciences Senior Honors Theses. Paper 26. http://doi.org/10.18297/honors/26

This Senior Honors Thesis is brought to you for free and open access by the College of Arts \& Sciences at ThinkIR: The University of Louisville's Institutional Repository. It has been accepted for inclusion in College of Arts \& Sciences Senior Honors Theses by an authorized administrator of ThinkIR: The University of Louisville's Institutional Repository. This title appears here courtesy of the author, who has retained all other copyrights. For more information, please contact thinkir@louisville.edu. 
From Colonialism to Neoliberalism:

Modernity and the State Production of a Bedouin-Transjordanian

National Identity

By

Amanda M. Yee

Submitted in partial fulfillment of the requirements for Graduation magna cum laude

and

For Graduation with Honors from the Department of Anthropology

University of Louisville

March 2013 


\section{Introduction}

The problematic of constructing a unified national identity poses an interesting question for a nation-state originally drawn up by European colonial forces. After the revelation of their clandestine Sykes-Picot agreement with France, British colonialists created Transjordan in 1921 as a means to appease their Arab allies, to whom they had promised a sovereign state in exchange for aiding European powers against the Ottomans. To govern the state, the British imported from the Hijaz (present-day Saudi Arabia) Emir Abdullah from the Hashemite tribe the tribe to which the Prophet Muhammad once belonged. The arbitrarily drawn boundaries of the new Jordanian state encompassed a number of heterogeneous, competing tribal groups who initially resisted the centralized leadership of the Hashemites; however, the regime conciliated members of these groups by way of offering them employment within the emerging civil service and enlistment in the national army. Throughout the years, as Jordan's Bedouin populations grew increasingly settled and urbanized, the regime began to collapse that identity with that of an encompassing East Bank/Transjordanian one, inclusive of those of nomadic and settled origins. Though not all Transjordanians necessarily claimed Bedouin origins, they nevertheless participated in a state-sanctioned system of forming political alliances along family and clan ties and using these links to maneuver the economic and bureaucratic realms (Ryan 2010), thereby contributing to the "tribalization" of Jordanian society. This practice laid the foundation for a Transjordanian national identity based on an overarching tribal affiliation and also loyalty to the Hashemite regime.

Nevertheless, various historical and political moments in Jordan’s relatively brief existence as a nation-state have challenged this constructed national identity. In 1948, the creation of the state of Israel coupled with the annexation of the West Bank and Jordan's 
acceptance of over 450,000 refugees fleeing the violence split the demographic of the state into that of Transjordanians of settled East Bank and Bedouin origins and Palestinians of West Bank origins. Eventually, the number of Palestinians and Palestinian-Jordanians in Jordan grew to surpass the number of East Bank Jordanians, and with that came the attendant resentment felt by the Palestinians that they were being ruled by a minority. Ongoing civil strife and clashes ultimately culminated with the events of Black September in 1970, a brief civil war fought between the state and Palestinian militants. Additionally, the 1980's Israeli campaign that “Jordan is Palestine," in which Prime Minister Ariel Sharon and the Likud party campaigned for Palestinian state within the Jordanian one, only ignited growing nationalist concerns among Transjordanians of losing their state to a non-indigenous population, signaling the need to establish a unified national identity by which to lay claim over Jordan proper. Nationalism, as broadly defined by Benedict Anderson, links the present to a mythologized past in order to assert the legitimacy of a trans-local community over a given territory. As such, this impulse was satisfied by way of drawing a cultural and historical link to the Bedouins indigenous to Transjordan.

However, this re-ignited nationalist endeavor did not solely emerge as an organic, populist effort. Since its inception, the Jordanian state (defined as the Hashemite Emir Abdullah working in tandem with British colonialists after 1921 and as a governmental body consisting of the Hashemite monarchy, Parliament, and a Prime Minister following independence in 1946) has consistently adopted methods of modernization from the West to cultivate a nativist identity to which the it could claim historical legitimacy, ultimately creating an authoritarian state and exclusivist polity and civil society inimical to Brian Singer's idea of an inclusive, democratic “contractual nation,” to which modernity aspires. This paper explores the institutional, political, 
and economic instruments that the state has utilized to first articulate this Bedouin link to the nation-state and subsequently reify it for the sake of regime security. It posits not only that the Hashemite regime acted as the primary architect of this national identity, first in tandem with the British in 1921 and then again following Black September in 1970, but it has also continuously deployed the imported tools of Western “modernization” - European-influenced administrative and military infrastructure, economic development, and political liberalization - to paradoxically satisfy these "primordial attachments” to kin affiliations (Geertz 1963, 1971) while maintaining the façade of universal citizenship typically characteristic of the Western understanding of the “contractual” nation-state. According to Singer, the “contractual nation” ideal to which Western modernity aspires is defined as "universalist in the sense that, in principle, individuals can become citizens of that nation, provided that they agree to submit to the laws that reflect the underlying concept,” as opposed to the “cultural nation,” which predicates citizenship upon “a common relation to some combination of historical memory, geography, kinship, tradition, mores, religion and language” (1996:310-311). Despite presenting itself to the Western gaze as “moderate” and democratic - most notably by the most recent King Abdullah’s regime - Jordan nevertheless has internally maintained a civil and political society which favors those of Bedouin-Transjordanian origins. How have the Hashemites, who originate not from Transjordan but from the Hijaz, linked themselves to this nativist national identity? The first section retraces the establishment of Transjordan as a nation-state and explores the manner in which the Bedouin national identity was first ossified under the supervision of the British and the Hashemites. The second section investigates how the new demographic reality in Jordan after the creation of Israel necessitated a new imagining of national belonging more inclusive of the Palestinians and how the state retreated to its discourse of an exclusivist, nativist identity following Black September. 
The third section studies the consequences of Israeli politics on Jordanian society, creating an imperative for the regime to retroactively construct a mythologized Bedouin history, and how this manifested in Jordan's tourism and heritage industries; the fourth section explores how regional instability and economic crisis solidified Jordan’s pivot toward IMF-directed neoliberal policies and what this turn meant for identity politics. Finally, the last section investigates how the effects of economic liberalization policies of the late twentieth century have marginalized the non-elite sector of East Bank Jordanians, and in turn, served to fuel an ultra-nationalist movement that threatens the stability of the regime today. In this way, this study problematizes within the local, Jordanian context the imposition of a colonialist modernization project under which the nation-state was originally conceived and under the direction that has continued to steer its course to this day.

\section{Theoretical Framework}

This study engages with Rogers Brubaker and Frederick Cooper’s research on identity (2000) and Geoffrey C. Bowker and Susan Leigh Star's study on classification systems (1999). Rather than uncritically accepting that all citizens are born with and possess an individual identity, this research explores Jordanian national identity as a manifestation of humans' impulse to impose categorizations on both themselves and others (Bowker and Star 1999:1; Brubaker and Cooper 2000:14). For this reason, it investigates Bedouin-Transjordanian identity not as a natural existent phenomenon, but implicates the role of the state in the process of "identifying." The state presents a case worthy of critical analysis, because it is “a powerful 'identifier,' not because it can create 'identities' in the strong sense [that is, identities as essentialized and immutable]...but because it has the material and symbolic resources to impose the categories, 
classificatory schemes, and modes of social counting with which bureaucrats, judges, teachers, and doctors must refer” (Brubaker and Cooper 2000:16). Although scholarship of the Middle East - particularly Middle Eastern anthropology -- is rife with studies of how subaltern groups "renegotiate" identities imposed upon them by an institution of power (Abu-Lughod 1990; Adely 2012; Deeb 2006; Layne 1989; Layne 1994), the state still remains the primary authority of constructing and reconstructing the identities that these groups "renegotiate" in the first place. Thus, the power of the state, and the instruments it utilizes to first create, and then re-enforce, these nationalist conceptualizations of self, I believe, are worthy of further study.

This study also applies Brubaker and Cooper's assertion of identities as categories of practice; that is, identities exist as "categories of everyday social experiences, developed and deployed by ordinary social actors...[and] used by 'lay' actors in some (not all!) everyday settings to make sense of themselves, of their activities, of what they share with, and how they differ from others” (2000:4). In other words, the state may socially promote these nativist identities, but the manner in which Jordanian citizens experience these identities and their effects and use them to understand the circumstances around them make them material realities. However, as the authors argue, this does not necessitate researchers adopting identity as a category of analysis - as an ontological social fact to be accepted as real and utilized as a lens of analysis. Likewise, the concepts of "nations" and "race" can be studied as categories of practice but not applied as categories of analysis (Brubaker and Cooper 2000:5).

Concomitant with placing Jordanian citizens neatly into ascribed identities of "East Bank origins" and "West Bank origins" is the segmentation of time into neatly distinguishable, demarcated categories. Jordan is not only geographically arranged around the urban centers of Amman, Irbid, and Zarqa in the north and the rural hinterlands of the south, these areas are also 
temporally distinguished according to the framework of modernization theory that the Hashemites inherited from British colonial forces. From the perspective of a Eurocentric understanding of social evolution in which civilizations evolve along a single, unilineal trajectory, contemporary Jordan exists as an "evolutionary enigma” (Massad 2001:106), at once "primitive" and "traditional" (in its emphasis on tribal identity and the roles that personal connections play within the social and political realms) while also "developed" and "modern" (in its urban character, its level of economic development, and its ostensibly democratic political system). The state has itself encouraged this spatio-temporal divide. On the one hand, it has historically nurtured a base of support in the Bedouin regions through reserving positions within the public sector exclusively for tribal members and manipulating electoral laws to facilitate their over-representation in parliament; on the other, it has also aggressively pursued economic development and funneled the majority of development projects into the urban metropolises. I bring attention to this divide not because I personally subscribe to a teleological interpretation of history; however, this model of modernization based on the Western standard directly informs Jordanian state policy and the development efforts it undertakes, thereby making it a material reality in the lived experience of many Jordanians. As such, like identity, we can understand modernity as a category of practice but not accept it as a category of analysis; that is, modernity (and the development discourses it produces) may be taken as an object of critical study without denying the nature of its social construction by hegemonic forces.

\section{The Beginnings of Transjordan: Incorporating Nomadic Tribes into the Political Entity}

Benedict Anderson describes the modern nation-state imagined as at once modular, that is, "capable of being transplanted, with varying degrees of self-consciousness, to a great variety 
of social terrains, to merge and be merged with a correspondingly wide variety of political and ideological constellations"; limited, in that each national entity would have distinct, delineated borders; and as a community, where the individuals within those borders perceive themselves sharing a common, ontological national identity (2006:4-7). Certainly, when British forces drew the borders of modern Transjordan within the geo-politically strategic region between the Levant and the Hijaz in 1921, they conceptualized a national entity congruent with Anderson’s blueprint. However, the nomadic tribal groups, which comprised roughly 46 percent of the total population (Massad 2001:56) within the newly drawn borders, posed a direct challenge to their colonial project. How could the state - the implanted Hashemite regime working in tandem with British forces - enforce these imagined boundaries and the idea of national citizenship among a population of competing, diverse tribes who were not spatially bound to the borders of the newly formed nation-state? How could it assimilate these tribes into the realm of modernity with their pastoral economy and lack of infrastructure? Palestinian former political advisor to King Abdullah II Adnan Abu-Odeh describes the temporal disconnect between the nomadic and the settled that the regime surely confronted:

When Emir Abdullah, the second son of Sharif Hussein bin Ali, the leader of the Arab revolt against the Turks, arrived in Amman on March 2, 1921, the country was as it had been under the Ottomans: poor, backward, and ungovernable...The country was ravaged by utter neglect. Its 250,000 estimated settled inhabitants were fragmented into four districts. The social organization was largely tribal, with marriage, discipline, local defense, and the individual's sense of social identity determined by tribal affiliation. Life was mainly pastoral...Health services were almost nonexistent, the educational system was extremely backward, and illiteracy was high...The Bedouin tribes were still nomadic and were contemptuous of villagers and townspeople. They always posed a threat to the sedentary, especially to the agricultural community during the drought seasons. Civil society was nonexistent (2000:13). 
Based on the teleological conceptualization of modernity, the nomadic were seen as "backward" while the settled were seen as slightly more developed but still primitive by European standards. Transjordan was not without potential though; the British believed that their influence could be the engine which drove the nation-state toward progress on par with Europe, characterized by urbanization, an industrialized economy, and civil infrastructure. To achieve this, the state would have to configure a way of unifying the tribes and incorporating them into the political fold. Thus, the Hashemite regime employed an imbricated dual strategy of simultaneously deploying instruments both "tribal” (invoking clan politics and establishing political links based on kinship relations of reciprocal benefit) and "modern" (importing from the British a legal and military infrastructure to enforce the legitimacy of the regime).

The monarchy based this dual strategy on first establishing itself as the "supratribe" of the Jordanian state, with Emir Abdullah serving as the tribal leader among his large "clan" of citizens. To solidify this connection, the regime invoked its own tribal link to the Hashemites, to which the Prophet Muhammad had belonged, and frequently visited high-ranking sheikhs and their families in the region. In their fieldwork among the Adwan tribe, for example, Andrew Shryock and Sally Howell illustrate the manner in which the Hashemites instrumentalized "house politics" to secure their position of power (2001). Tribal elders relayed to the anthropologists that following an unsuccessful assassination attempt against the new emir led by Majid and Sultan, two of their patriarchs, Abdullah and his cavalry paid several visits to the family. Each time, the statesmen were treated to ostentatious displays of hospitality (karam), including coffee and tea services and lavish, expensive feasts. According to Shryock and Howell, “To give hospitality without expecting a return is to affect superiority” (2001:262); indeed, the Adwanis were cognizant of the fact that Emir Abdullah needed the cooperation of the tribe for 
the stability of his regime, but the tribe did not necessarily need him. The ability to not only to provide, but to provide extravagantly, indicates a position of power. Therefore, the house functioned as a space by which power paradigms were renegotiated, with hospitality playing a pivotal role in the eventual reconciliation between the emir and the Adwanis. The family recalled the relationship between Emir Abdullah and Majid after the reconciliation as "a relationship between two households," with the emir securing positions for Adwani family members within the government and Majid providing the emir counsel on how to appropriately host other local tribesmen (Shryock and Howell 2001:262). The power paradigm was quickly reversed, however, following the death of Majid. The Hashemites could now reciprocate the Adwanis’ hospitality by absorbing Majid's wife and sons as their own personal dependents. Today, the family members conceptualize this cunning political maneuver "as a triumph of the Hashemites over the Adwan only a status superior would offer protection in this way” (Shryock and Howell 2001:263-264). The assimilation of the Adwan tribe into the realm of political dependency on the state was now complete. The remainder of this section will explore how the regime created a similar political and economic dependency on a macro level.

The story of Emir Abdullah and the Adwan tribe elucidates the manner in which the regime engaged in mechanisms of kin-based, reciprocal relations to incorporate the Adwan tribe into its political sphere. In addition to the Hashemites utilizing local customary practices to win over initially resistant tribes, they also exploited more overtly coercive measures through “modern” legal means. First, the state undertook a discursive project, assuming the authority to decide which populations it could categorize as “Bedouin” and “not Bedouin.” According to anthropologist Linda Layne, “Bedouin” (literally in Arabic: one who lives in the badiya, or desert) was originally a general term “[referring] to pastoral nomads and encompasses a 
constellation of characteristics - residence location (the badiya), residence type (goat-hair tent), residence pattern (nomadic), and a particular form of pastoralism (camel herding)” (1994:13). However, the tribes to which the term was applied referred to themselves using a much more complex set of vocabulary that transcended the state’s Bedouin/not Bedouin dichotomy, identifying themselves by their tribal confederation, tribe, family name, lineage, or simply as arab (Layne 1994:15). Furthermore, some tribes which the state identified as "Bedouin” did not strictly adhere to nomadic lifestyles, limit their herding to exclusively camels, or practice intertribal raiding. Some tribes lived among the settled (hadar) for a duration of the year, from whom they would purchase grain, weapons, and clothing. Others paid a tax (rawa) to rival tribes in exchange for protection. The state's discursive identifying practices and successive settlement policies would come to destroy these existent symbiotic relationships and economic exchanges. Through these policies, state recognition of heterogeneity among the tribes was diluted; the regime classified tribes, which formerly identified themselves as Adwan, Abbadi, Bani Sakhr, and Balga, among others, as simply falling under the umbrella term of "Bedouin." The state took full control of this identification process; it dictated the parameters of belonging and then buttressed them through legal measures aimed directly at this population. One such mechanism, the Bedouin Control Law of 1924, listed as “Bedouin” nine different tribes (Layne 1994:17), thus subjecting them to a separate legal structure distinct from the non-Bedouin or "settled" populations. This law, which was updated in 1929 and again in 1936, aimed to territorialize these nomadic tribes by way of establishing settlement locations and essentially enforcing martial law within these territories to restrict individual movement. Inter-tribal raiding and the crossing of Jordanian borders now became illegal, and those who resisted were subject to prison sentences and hefty fines. 
To enforce these new laws, the state relied on three established military institutions, which directly enlisted Bedouins into their ranks: the Royal Air Force, the Arab Legion, and the Desert Patrol. The Royal Air Force functioned to defend the regime against those who forcefully opposed its rule. The Arab Legion, headed by British military officer John Bagot Glubb, was originally conceived as an army to protect the emir but eventually "became mainly a police force involved in crime prevention, tax collection, and arresting offenders, as well as responsibilities over immigration and passport control, motor licensing, and traffic control” (Massad 2001:104). Finally, the Desert Patrol, which Glubb created, guarded the newly drawn-up borders that Transjordan shared with neighboring Saudi Arabia, Iraq, and Syria. These military institutions functioned as an intermediary between the tribes and the nation-state; not only had the state successfully codified its settlement project into law, it had additionally recruited into its ranks those very members they had settled to enforce these laws. This strategy served the state's purpose of "[nationalizing] the Bedouins through shifting their loyalties from the tribe to the military and ultimately to the nation-state that this military was supposed to protect" (Massad 2001:59). Additionally, with the creation of the nation-state came the opening of a new public sector and civil bureaucracy; the regime appointed almost exclusively Bedouins to these institutions, strengthening the economic link between tribe and state. The regime's settlement venture effectively destroyed the Bedouins’ pastoral economy but created a new one entirely dependent on state institutions. When droughts in the late 1920's and early 1930's decimated crops in the region, the state offered to those Bedouins devastated increased employment within the British-owned Iraq Petroleum Company, the military, and the public sector (Massad 2001:59). Thus, the regime laid the framework for its "authoritarian bargain" with the Bedouins - an exchange of their political loyalty for promised economic security (Greenwood 2003:250). 
In conclusion, when the British arrived in 1921 to erect a nation-state within Transjordan, the nomadic tribes represented a temporal lag inimical to their modernization project. To guide the tribes into the jurisdiction of the nation-state and thus into the realm of modernity, the regime introduced an imbricated strategy employing methods both clan-based and institutional. Acting as the "supra-tribe" of these heterogeneous tribes, the Hashemites paid visits to local families and worked within this framework to establish favorable political relations. At the same time, they created a legal and institutional framework to first identify who fell under the category of "Bedouin" and then created laws specific to those individuals, reifying this discursive construction. This functioned not only to settle once nomadic tribes but also to unify them under one national identity. The regime then invoked its role as supratribe to appoint members of this group into its political and military infrastructure, thus eclipsing the pastoral economy with one predominantly dependent on the state. Thus, the state discursively constructed the Bedouin national identity and reified it through an imported, legal practice. Loyalty to the regime, another characteristic of this new national identity, increased concomitantly with economic dependency. These practices produced the paradoxical outcome of an embryonic "modern" nation-state on the one hand and the strengthening of tribal-based affiliation on the other.

\section{The Reshuffling of Jordanian National Identity: Before Black September and After}

The creation of the state of Israel in 1948 ushered in new concerns for the Hashemites in terms of maintaining a cohesive national identity. Jordan, which had gained full independence from Britain in 1946, annexed the West Bank after the 1948 war, absorbing its population of 340,000 Palestinian inhabitants. Additionally, the state had also accepted approximately 450,000 Palestinian refugees expelled from what is now Israel (Nanes 2008:89). These two events 
dramatically reconfigured Jordan’s social fabric anew, with Palestinians now outnumbering Transjordanians two to one. King Hussein, who assumed the throne in 1953, reacted accordingly, moving national discourse away from a particularistic Bedouin identity toward a more integrative pan-Arab, pan-Islamic one. According to Stefanie Nanes, this new "hybrid” national identity was predicated on four components:

first, the monarch as the father of the larger Jordanian family; second, the Hashemite commitment to Arabism as evidenced by their leadership of the Arab Revolt; third, the regime's stated commitment to Palestine, particularly support of Islamic holy places and its providing a haven for Palestinian refugees; and finally, the unity of the two banks and the two peoples. The regime consistently stressed the slogan "one Jordanian family with Jordanian and Palestinian branches" (2008:90).

Indeed, King Hussein often publicly referred to the Palestinians as the muhajireen (the followers of Muhammad who immigrated to Medina) and the Transjordanians as the ansar (the citizens of Medina who took in the muhajireen). This Islamic metaphor served to remind Jordanian citizens of their duty to accept the Palestinians as their neighbors and to imply that "just as the Muslim nation could not revive itself without these two elements - the muhajireen and the ansar - so too would Jordan would not be able to exist without these two" (Fruchter-Ronen 2008:248). Even after Jordan lost the West Bank to Israel in 1967, Hussein still imagined a unification of the two banks as part of a greater, pan-Arab state.

Despite this public discourse of integration, socio-economic and political fault lines had emerged between the Palestinians and Transjordanians. The state "viewed the Transjordanians as more loyal and reliable than the recently uprooted and newly enfranchised Palestinians,” and in order to "insure continued Transjordanian loyalty...provided subsidies and preferentially recruited key tribes into various parts of the state apparatus” (Brand 1995:48). Thus, the regime 
retained its traditional base of political support by continuing its policy of reserving the majority of military and government positions exclusively for Transjordanians. As the Palestinians had come to dominate the private sector within Jordan, Transjordanians tacitly accepted their overrepresentation within the public sector as a necessary means of balance. From the perspective of Transjordanians, the Palestinians could not expect to control both the economy and the state, especially since they were not even “true” Jordanians (Nanes 2008:93). This continued policy of appointing those of East Bank origins to the state bureaucracy further solidified Transjordanian loyalty to the regime while marginalizing the majority of Palestinians. Palestinians, meanwhile, rejected Hussein's integrative attempts, perceiving them as normalizing the loss of a state to which they hoped to eventually return.

Within the refugee camps in Jordan, resistance fighters transformed these spaces into embryonic Palestinian "states within a state," wherein they recruited new members, organized propaganda campaigns against the Jordanian government, and conducted guerrilla operations across the border into Israel. Tensions increasingly mounted as these fighters violently clashed with Jordanian police officers and security forces, set up makeshift roadblocks, kidnapped foreign diplomats, and began to undermine loyalty of the regime's Transjordanian base through recruiting Bedouin tribes to join the "Palestinian revolution" (Fruchter-Ronen 2008:247). As the number of Palestinians and Palestinian-Jordanians continued to increase, so did their underlying resentment of the Hashemite monarchy and its integrative efforts. Anticipating a potential fissure that would threaten security of his regime, Hussein “recruit[ed] once again the trans-Jordanians' support, beginning with the tribes... and arranged a series of meetings with the heads [of them]" (Fruchter-Ronen 2008:249). Hussein could not quell the Palestinians’ residual resentment, however, and clashes between militant factions and the state culminated in a civil war known as 
Black September in 1970. In response, the regime launched a counter-attack, and fighting continued for ten days until a ceasefire was reached on September $23^{\text {rd }}$.

Certainly, the lines of nationalism were not clearly demarcated during battle - many Transjordanians sympathized with and fought alongside the Palestinian militants against the Jordanian army, and many Transjordanians and middle-class Palestinians alike resented the violent upheavals that the organization brought. Moreover, there were many individuals in both groups who remained neutral during the clashes. The Jordanian regime, however, saw the imperative to unify a fragmented society and restore order to the country. While many individuals considered Palestinian and Jordanian identities as fluid and overlapping before Black September, Hussein bifurcated them ex post facto into two mutually exclusive categories; either an individual was Palestinian or he was Jordanian, but he could not choose to identify as both. The state undertook an "East Banker first” initiative, a campaign of "Jordanization," in which the regime tested the political loyalty of Transjordanians and Palestinians alike. According to Margaret Lock and Nancy Scheper-Hughes, the idiom of the body politic imagines the state as a “human body in which what is 'inside' is good and all that is 'outside' is evil...leading to purges of traitors and social deviants” (2010[1990]:545). In this way, the events of Black September impelled King Hussein to both identify and purge those individuals making the nation "sick." First, as part of the ceasefire agreement, he routed the Palestinian guerillas out of Jordan. Secondly, immediately following the clashes, the state undertook a major campaign of recruiting Transjordanians into its military ranks, excluding both Palestinians and Palestinian-Jordanians (Massad 2001:213). Then, to further distinguish Jordanian national identity, the government immediately replaced Palestinians within the civil sector with Transjordanians, as a "prize" awarded for the latter's political support during the civil strife (Fruchter-Ronen 2008: 254). In 
further fulfillment of this Jordanization endeavor, Hussein appointed the anti-Palestinian Wasfi Al-Tall as prime minister in October of 1971. Al-Tall continued the campaign initiated by Hussein against workers within the public sector suspected of having participated in subversive activity against the regime. For example, one such victim of Al-Tall's campaign was Mashhur Hadithah al-Jazi, the Jordanian Military Chief of Staff and member of the Huwaytat tribe in the south, who was placed under house arrest for sympathizing with the Palestinian guerillas. As such, not only were hundreds of Palestinians removed from their positions, but many Jordanians as well. The Jordanization of state bureaucracy established a discriminatory institution, which East Bankers could easily navigate through personal and tribal connections (wasta), while Palestinians faced great difficulty in such simple tasks as renewing a passport or driver's license or obtaining a scholarship (Brand 1995:53). Palestinians and Palestinian-Jordanian businesspeople often hired East Bankers as intermediaries, preferably with high personal connections, to assist in directing their paperwork through the Transjordanian-dominated bureaucracy; unexpectedly then in this way, the state indirectly generated a new labor market for East Bank Jordanians (Abu-Odeh 2000:197; Massad 2001:267).

Furthermore, Hussein returned to the pre-1948 discourse of Bedouin national identity as an "authentic” Jordanian national identity. In order to re-solidify this Bedouin national identity, the Hussein regime established a number of councils and conferences devoted to discussing tribal traditions and promoting the welfare of Bedouin tribes. One of them, the Council of Tribal Leaders (majlis shuyukh al-ash'ir) was established on July 31, 1971 to discuss the elevation of living, education, and health standards among the Bedouin tribes (Massad 2001:61). Hussein’s brother, Prince Muhammad, presided as president over the twelve to fifteen appointed tribal officials. Two years later in 1973, the council passed a statute, the Unification of Tribal Customs 
(tawhid al-adat al-ash'irriyyah), which legally merged the diverse traditions celebrated by the Bedouin tribes. Consequently, the state not only re-constructed the authenticity of the Bedouins as "true" Jordanians, it also established itself as the primary authority by which to dictate which of their celebrated customs were considered "authentic" before the law. So hegemonic was the regime's tribalization of its polity and society that the Circassians and Chechens in Jordan formed their own "Circassian-Chechen Tribal Council” to represent themselves politically, despite sharing few cultural similarities with the Bedouins (Al Oudat and Alshboul 2010:71).

Media played a critical role in the dissemination of this revived Bedouin identity. True to Benedict Anderson's assertion that the spread of print capitalism encouraged the production of a national consciousness (2006:37), the state not only deemed which Bedouin customs were authentic but which texts as well. Whereas during the 1950's and 1960's, Jordanian schools had co-opted textbooks from Syria, Iraq, and Egypt, the Ministry of Education assumed authority of publishing all textbooks in Jordan by the late 1970's (Nasser 2004:228). These new textbooks reflected a more exclusivist Jordanian national ideology, as opposed to the pan-Arab, panIslamic aspirations that the old textbooks espoused. Furthermore, Al-Tall shut down Palestinianrun newspapers, as well as newspapers he believed to be sympathetic to the Palestinians, such as Amman al-Masa, Al-Difa, and Al-Sabah (Massad 2001:246), replacing them with the state-run, Transjordanian-edited newspapers Al-Urdun and Al-Ra'y. Other aspects of the state's print and media campaign to retroactively construct Jordan’s Bedouin history included creating a new market for Bedouin poetry, folkloric monographs, historical works, and adapting oral traditions into print (Abu-Odeh 2000:244; Shryock 1995:325;); developing soap operas depicting "Bedouin life” on television (Massad 2001:250), such as Fares and Nujud in 1974, in which Palestinian actor Mahmoud Said portrayed the lead role of Bedouin character Fares; and popularizing 
Bedouin folk songs on the radio. In an example of the latter initiative, the Lebanese singer Samirah Tawfiq saw a revitalization of her career in the mid-1970's in Jordan by capitalizing on the new "traditional” song market (Massad 2001:72). Tawfiq often performed in elaborate costumes inspired by Bedouin dress and sang in Bedouin dialect. Thus emerged a renewed epistemology of the Bedouin linked to their legitimacy as the "true” inhabitants of Jordan. By way of controlling print capitalism and the media, the state legitimized the BedouinTransjordanian history while virtually censoring the Palestinian narrative.

Of course, to categorize identities is not purely a discursive exercise - the act carries with it deep consequences for those subjected. Categorization bisects once overlapping groups, and the divides deepen further as the individuals within those groups buy into nationalistic fictions and counter-fictions. Abu-Odeh posits that, in the moment, the clashes between the state and the Palestinian factions were not considered a civil war within Jordan but retroactively framed as such by the regime, and Palestinians and Jordanians subsequently followed suit (2000:183). After Black September, “[the] Palestinians spoke of huge casualty figures, massacre, and rape, particularly on the part of Bedouin units in the Jordanian army... Jordanians had their own atrocity stories and myths, and these tended to dwell on the dishonesty and ingratitude of the Palestinians” (qtd. Lalor in Abu-Odeh 2000:183). The state utilized the media and its bureaucratic institutions as instruments of discrimination against the Palestinians after Black September; this maneuver created a parallel effect of both validating Transjordanian nationalists' loyalty to the monarchy while also legitimizing Palestinians' already nascent concerns of marginalization at the hands of the regime. Additionally, the 1974 Rabat Resolution, which recognized the Palestinian Liberation Organization (PLO) as the "sole legitimate representative" of the Palestinian people, forced Hussein to relinquish his claim of speaking on behalf of the 
Palestinians and his vision for a unified pan-Arab state, thereby deepening nationalist ideologies on both sides. That event, coupled with the government's final administrative disengagement from the West Bank in 1988, "produced a Jordanian nation that conformed more closely to the modern, Western model of nation by clarifying and confirming the Jordanian 'Self' and the Palestinian 'Other” (Layne 1994:26). National identities were then dialectically strengthened as each side internalized these bifurcations, reifying the Other, and basing themselves on what the other was not. Consequently, the activities and rhetoric of the state directly inflamed nationalistic sentiments on both the Palestinian and Transjordanian sides.

\section{Asserting Bedouin National Identity on the International Stage}

Once the state had solidified its cultural and historical link to a mythologized Bedouin past internally, regional politics outside Jordan's borders necessitated the imperative to project its national identity externally. This imperative was partially incited in 1977, when the rightwing Likud party ascended into power in Israel, and Ariel Sharon was appointed Minister of Defense. During this period, Israel officially began its settler-colonial expansion into the West Bank, which Jordan feared would force hundreds of thousands more Palestinians into its borders. The state’s anxieties were further exacerbated when Likud won Israeli elections again in 1981 and maintained its position of West Bank settlement. Additionally, the party, along with nowPrime Minister Ariel Sharon initiated its "Jordan is Palestine” campaign, calling for an alternative homeland (al-watan al-badil) for the Palestinians to be implanted within Jordan due to its already high population of Palestinian refugees. Similar to how early Zionists imagined Palestine as a land without a people for a people without a land prior to colonization, the Likud party justified the relocation of Palestinians to Jordan through conceiving it as a "country without 
a people or a history of its own” (Layne 1994:25), as it only had only been recently established as a state by the British after World War I. Situated in a national contest between Palestinian resistance and Israeli aspirations of relocating a Palestinian state within Jordanian borders, the regime ramped up its Jordanian identity as Bedouin identity state project. As the original inhabitants of Transjordan, the Bedouins were made to represent a historical territorial claim over the nation-state, linking past and present. This claim had already been achieved locally after Black September, but now, the state saw the obligation to cast this representation internationally in order to stake legitimacy over its own territory.

In no other realm was this more apparent than the tourism and heritage industries. The state actively developed its tourism sector in the 1970's and 1980's; consequently, the income generated from this industry increased from JD 35.7 million in 1970 to JD 160 million in 1980 to JD 183 million by 1985 (Layne 1994:101). The tourism and heritage industries not only anchored within Jordan a historical legitimacy, but they also functioned to illuminate an evolutionary progression to the Western observer, tracing a linear development from primitiveness to modernity. According to Shryock, "Historic preservation, the tourism industry, and cultural resources - like democratization, transparency, human rights, and free markets - are concepts on loan from North America and Europe. They appeal to many Jordanians because they define progress and attract much-needed resources from elsewhere. International tourism and development could not function without these globalizing discourses and the local worlds they create” (2004:44). In other words, progress of a society is signified through a conscious assertion of a tangible, definitive past to hold up in contrast to its more "advanced" contemporary self; the practice of displaying a retroactively constructed genealogy to highlight this disparity between past and present self that is the tourism and heritage industries was itself adopted from the 
Western colonial state (Anderson 2006:163-185) . Similar to how Emir Abdullah imported British infrastructure in Jordan's early stages to mold it in the likeness of the European nationstate, the tourism and heritage industries appropriated the Western practice of historic preservation to conform to the modernizationist thought that Jordan evolved along a single teleological schema like its European counterparts. With this concept in mind, The Ministry of Tourism and Antiquities promoted the image of the Bedouin as repositories of an "authentic" Jordanian heritage, and locations such as Wadi Rum and Petra - sites where the "traditional" Bedouin way of life was still preserved -- became popular attractions for Western tourists; thus emerged a material culture surrounding the Bedouin for a transnational audience to consume. Heritage became encapsulated in material objects, readily available to be displayed or sold. The government devoted entire museums, such as the Jordan Folklore Museum (1975) and the Jordanian Museum of Popular Traditions (1971), to presenting tribal artifacts including traditional women's dresses (dilug), jewelry, and even banal everyday objects like utensils for preparing coffee, tea, and bread. Replicas of these artifacts are frequently sold to tourists as souvenirs in shops in downtown Amman, Wadi Rum, and Petra. By way of the tourism enterprise, the history and heritage of the Bedouin came to be known and represented through reductive symbols -- coffee pots, teacups, knives, clothing, and popular images, such as that of camels and desert for Westerners to consume.

One example of this metonymic display of heritage occurred during the 1994 signing of the Jordanian-Israeli Peace Accords. During the ceremony, the representatives of both parties were accompanied by a young girl bearing a flower bouquet for the other, the significance being that their grandfathers had been killed during the 1967 war. Israeli prime minister Yitzhak Rabin brought along a blonde girl, European in appearance, and dressed in Western-style clothing. 
Conversely, the young Jordanian girl escorted by King Hussein was adorned in a traditional Bedouin woman’s dilig. Joseph Massad notes of this choice, What was interesting about the Jordanian girl was not so much that no Jordanian girl dresses like this anywhere in modern Jordan, but that no Jordanian girl has dressed like this ever. The fashion the Jordanian girl wore to the signing ceremony was that of an adult woman of tribal heritage, which today is worn by older women who did not succumb to the march of Western modernity and its fashion industry in the country - it was certainly not a dress for a prepubescent girl (2001:99).

National representations leave little room for nuances such as this. The signing ceremony provided an opportunity for the state to assert its national identity on an international stage; the dress the young Jordanian girl wore that day was imbued with the aspirations of the state's national project. It symbolized a Jordan predating the contemporary era, attesting to the international community that, like other nation-states, Jordan had a history, a national identity, and a veritable claim to its territory.

Just as Bedouin clothing and artifacts become metonyms of an "authentic" culture, the Bedouin was reduced to a "simulacrum” of his former self (Layne 1994:103; Massad 2001:75), greeting foreigners at popular tourist attractions and personifying an exoticized, primitive Jordanian history, in its modern realm. Indeed, in their account of retracing the journey of T.E. Lawrence through the Arabian Desert, Edward Nevins and Theon Wright describe their encounter of the Bedouin the first day: "It was as if I had suddenly found myself in a world of the past, unrelated to my present existence and perhaps more akin to that of The Arabian Nights" (1969:53). Nevins and Wright undertook their journey in the 1960’s, but the same Orientalist sentiment exists today. This temporal disconnect for the Western observer is further illuminated in a recent article about the 2010 Arab uprisings, which describes Jordan as a "quiet kingdom of 
luxury hotels, impoverished mud hut villages, and exotic desert castles” (Murphy 2011). This image is a conscious effort by the state to present Jordan specifically for international audiences "fascinated by cultural variations in space that can be interpreted as discontinuities in time" (Shryock 2004:45). Certainly, the tourism industry packages the Jordanian experience for the Western tourist as one of spatio-temporal juxtaposition: the novelty of a "primitive," desertdwelling way of life co-existing simultaneously with the "modern" urbanization of Amman and Irbid.

Through these Bedouin metonyms and simulacra, the foreign tourist can also comfortably disengage from his own modernity and participate in exoticized, primitive Jordan without engaging too critically in the nuances of contextualized history. In her article analyzing the commodification of mansaf, the Bedouin dish of lamb, rice, and yogurt which was nationalized in 1971 by the state as the official dish of Jordan (despite also being consumed by certain populations in Iraq, Palestine, and Syria), Sally Howell opined that Jordon's heritage industry, "through their polished websites and glossy promotional materials, mediate mansaf and other 'heritage products' for tourists and local elites, who can consume, along with lamb and rice, their own modernity, their own distance from (and lingering appreciation for) the lifestyle that supposedly gave rise to mansaf in the first place” (2003:227). Likewise, when the first class Forum Petra Hotel opened in Petra in 1983, the manager - an Englishman - contracted members of the local tribe to obtain ingredients for and prepare a daily feast of mansaf for the hotel guests. The tourists would then be led to the site of the mansaf, the monastery in Petra (al-dayr), a daunting hike of about 850 steps uphill, followed by donkeys carrying cases of wine and beer. After the long hike, the guests would eat the mansaf together, followed by a traditional dance performance by the Bedouins who prepared their feast (Shoup 1985:283). Here on display for the 
Western audience was a glimpse of "genuine” Bedouin hospitality (karam), readily available for their consumption.

This commodified motif of hospitality continues to this day. When I was studying Arabic in Amman the summer of 2012, I traveled with a group of students to Wadi Rum one weekend. The hosting Bedouin tribe met us at our tour bus by the side of the road and drove us in their trucks into the desert to the "traditional" tents they erect specifically for visiting tourists. Once night fell, we took part in a communal dinner that the Bedouins had cooked using an underground oven ( $a l$-zarb) buried beneath the sand. During dinner, they treated us to entertainment of traditional folk music and dancing (dabke). After dinner, they built a fire, and we foreigners formed a circle and listened intently as the Bedouins recited local folk stories and poetry in Arabic. In the morning, after eating the breakfast and drinking the coffee they had prepared, they led us on an eco-adventure excursion around the desert, stopping at a number of high rock mountains, which we would climb and admire the view from the top. After the climb, we would descend and rest at a nearby camp. At the camp, we would remove our shoes, walk around the tent and admire the excavated fossils, coffee pots, knives, and jewelry that the Bedouins had displayed for sale. Then we would leisurely sit for half an hour while the members of the tribe walked around, serving us tea. This occurred after each climb, at each stop. Appropriately, when our weekend-long excursion ended, the Bedouins led us out of the desert to a paved urban road lined with restaurants and more souvenir shops, where we once again stopped to browse, shop, and drink tea.

This is the place that the state has mediated for the Bedouin in the globalized economy extending hospitality as part of capitalist transaction, as a conduit by which to sell goods. Through the aforementioned tour package and others similar that the tourism industry offers, I, 
along with other Westerners, could temporarily suspend our own lives within the "modern" realm and experience Jordan in its primitive state (albeit with gift shops). Whereas the museum exhibits the national artifact, the tour package attempts to embed it within a contextualized setting - a simulation of Bedouin life in earnest -- for us to observe and, eventually, purchase. In this manner, the state reproduces the metonyms by which the international audience has come to know the Bedouin: deserts, tents, camels, tea, kuffiyehs. By encapsulating history into consumable goods, Jordon asserts and performs its national identity -- and by extension, its legitimacy as a nation-state -- within the increasingly interconnected capitalist world order.

\section{Jordan's Turn Toward Neoliberalism: Economic Crisis, Political Liberalization, and Regime Security}

Though Jordon's tourism industry flourished during the 1970's and 1980's, it could not singlehandedly save the state from a looming economic crisis. Having few natural resources it could exploit, Jordan's survival was predicated on its existence as a semi-rentier state. That is, the state of the economy depended mostly on outside sources, such as foreign aid (from the United States, United Kingdom, and other Arab states) or remittances sent back by migrant laborers. Jordan’s economy directly benefitted from exporting thousands of Palestinians and Jordanians to Saudi Arabia and Kuwait after the 1973 oil embargo that placed regional financial prowess into the hands of the Gulf States. However, when this market contracted in the late 1970's and early 1980's following the Iranian Revolution and Iran-Iraq War, and the state could no longer depend upon labor remittances or bilateral loans from the Arab states, Jordan was forced to turn to the World Bank and the International Monetary Fund (IMF) in April of 1989 for assistance. Though Jordan had pursued some small-scale structural adjustment attempts in the 
mid-1980's, the loans granted by the IMF and World Bank signaled the state's definitive pivot toward neoliberal policy in earnest. Geographer and anthropologist David Harvey describes neoliberalism as a mode of political and economic rationale influenced by economists Milton Friedman and Friedrich Hayek, which "proposes that human well-being can best be advanced by liberating individual entrepreneurial freedoms and skills within an institutional framework characterized by strong private property rights, free markets, and free trade. The role of the state is to create and preserve an institutional framework appropriate to such practices” (2005:2). Neoliberalism on the global scale is furthered through financial institutions such as the World Bank and the IMF (whose primary donors include the US, the UK, Japan, Canada, and Germany), which make loans to countries conditional upon deregulation, the state reducing social services and financial expenditures, creating private markets where those once social services existed, and lifting subsidies on food and fuel. Concomitant with the economic competition of neoliberalism is the concept of democratization -- the extension of competition among organized parties representing the interests of different political groups within the structure of a democracy. Of course, the imposition of liberalization policies at the hands of the IMF and the World Bank is embedded within an international modernization project, a universalizing enterprise of Eurocentric Third World development aimed at pulling these nations into an economic orbit in which the West was at the center, characterized by privatized industry and free markets. Accordingly, Jordan agreed to a five-year structural adjustment plan to secure its \$125 million loan from the IMF and an additional \$100 million loan from the World Bank (Ryan 1998) and commenced its economic and political restructuring.

Due to the scaling back of the public sector and security forces that the conditions of these loans necessitated, the state could no longer sustain its "authoritarian bargain" - economic 
security through bestowing jobs in exchange for political support (Abu-Odeh 2000:244;

Greenwood 2003:250) -- with the Transjordanian base upon which it normally relied. Additionally, as the private sector was primarily dominated by middle-class Palestinians, the Transjordanian nationalists complained of the new austerity measures directly benefitting this sector of the population. Therefore, according to Scott Greenwood, the pivot toward neoliberal policy also signaled a turn to a "new liberal bargain" in the political realm to satisfy the regime’s traditional base of support (2003). In 1989, as part of its liberalization reforms, the Jordanian government embarked on a series of steps to democratize its political system, which would ostensibly allow for better demographic representation, but in reality manipulated electoral laws to gerrymander votes from the tribal areas of the East Bank hinterlands.

The roots of this political restructuring endeavor dated back to 1984, when the Islamic Action Front (IAF), the political arm of the Muslim Brotherhood in Jordan consisting largely of Palestinian refugees, as well as the main opposition to the monarchy, defeated Transjordanian loyalists in lower parliamentary (majlis al-nuwaab) elections. In response to the election results, King Hussein collaborated with a ten-person committee the following year comprised of Transjordanian nationalists to implement a new electoral law, which would give the appearance of political legitimacy in the form of democratic reform while encouraging citizens to vote along tribal lines. The proposed law redrew the electoral districts smaller and additionally decreased the number of seats in each one in anticipation that the reduced number of seats would encourage individuals to vote along kinship ties. Furthermore, votes were disproportionately redistributed among the districts. For example, in 1986, the Amman governorate consisted of 38.7 percent of the East Bank population but was only allocated 23.9 percent of the total East Bank seats. The city of Amman itself comprised 29.8 percent of the East Bank population but was only given 9.9 
percent of the seats. Conversely, Kerak, which only held 4.2 percent of the population, was given 12.7 percent of seats (Greenwood 2003:253-254). The law was a direct attempt to over-represent the rural areas, home to the monarchy's tribal bases of support, and under-represent the urban areas, which largely consisted of Palestinians and Islamist-supporters. The proposed electoral law was approved March $27^{\text {th }}$, 1986 and went into effect for the 1989 parliamentary elections. However, the plan backfired, and the opposition swept the majority of the seats in parliament (59 percent), with the Islamists winning 34 of the 80 seats (Greenwood 2003:254). The oppositiondominated $11^{\text {th }}$ Parliament, with its vocal campaign to cancel the austerity measures imposed by the IMF, posed an obvious obstacle to the regime. Furthermore, Jordan's refusal to take a public stance on Iraq's invasion of Kuwait in 1990 prompted both the US and the Gulf states to cut off aid to the state. Without this aid, the state needed the IMF loans more than ever to cover the more than $\$ 8$ billion in debt it had accrued. The economic crisis was further exacerbated by the 200,000 to 300,000 Palestinians and Palestinian-Jordanians living and working in Kuwait who returned to Jordan after being expelled by the Iraqi occupation. The new wave of refugees into the state drove up unemployment rates, food and housing prices, and created a strain on public services (Brand 1995:36), furthering nascent tensions between Palestinians and Transjordanians. To alleviate this economic crisis, King Hussein agreed to participate in the 1991 Madrid Conference, a peace process initiative co-sponsored by the US and the USSR. Hussein hoped through this conference to re-establish positive relations with the US and Gulf States, thereby restoring aid to the country and perhaps allowing for some of its financial debts to be forgiven. However, Jordan's decision to participate in the conference was received unfavorably by the Jordanian population and the rest of the Arab nations. In the wake of this decision, Hussein saw 
the imperative to silence the opposition and engineer a new legislative body for the sake of regime security.

The nexus of these political and economic forces compelled the government to establish the Single, Non-Transferrable Vote (SNTV) or the "one man, one vote” electoral law in 1993. Under the previous law, citizens were allocated the same number of votes as seats available within that district, and they were free to spread those votes among different candidates or use them all on one candidate. Now, given only one vote, individuals were encouraged to vote along tribal and kinship lines, rather than ideological ones. The manipulation of the electoral law allowed the government to re-strengthen its ties to its Bedouin constituents under the guise of pursuing further democratization of its political system. The policy of over-representation of the tribal East Bank hinterlands was still retained under SNTV, with the modification that now individuals were only allocated one vote per person. As expected, Bedouin loyalists swept the 1993 elections, reducing the opposition’s 59 percent majority in the previous parliament to a 30 percent minority (Greenwood 2003:257). The results of the election led to the further tribalization of Jordanian society and government, confirming Bedouin and Transjordanian claims that their origins made legitimate their right to direct their state in political affairs. Furthermore, under this new liberal bargain, elected officials could use their authority to protect their constituents from the deleterious economic effects of the harsh austerity measures; corruption and nepotism under the new bargain ran rampant as a result. Therefore, the "new liberal bargain” was in fact, merely an adaptation of the old “authoritarian bargain.” Bedouins and Transjordanians could continue to exchange political loyalty for economic security; however, economic and political liberalization policies ushered in a new era for the Jordanian state, in which it could instrumentalize elections to strengthen identity politics and satisfy its 
traditional support base. Ostensibly, Jordan appeared as a neoliberal success story, with its implemented economic adjustment measures and political pluralism. Through this approach, the Jordanian state could demonstrate to the international community that it was in step with the neoliberal modernization project - that it was, in fact, Westernized, moderate, and democratic -while internally reconstructing a system to strengthen tribal identity and kinship ties.

When Hussein's eldest son, Abdullah II, ascended to the throne in 1999, he continued the policies of the new liberal bargain first undertaken by his father. The Western-educated Abdullah has defined his reign as one of moderation, progress, and peacekeeping -- a supposed anomaly in a region rife with political instability and underdevelopment. Abdullah often publicly positions himself as benevolent overseer, patiently guiding his nation toward modernization and democratization. Despite retaining his father's implemented SNTV law, Abdullah has publicly emphasized the path toward political liberalization that his government has taken. This has often entailed publicity campaigns where the king traipses from one media outlet to the next, invoking the grammar of a familiarized teleological evolutionary schema, wherein Jordan trails behind the US and Europe but remains ahead of other Arab states. For example, on September 25 ${ }^{\text {th }}$, 2012, Abdullah granted Jon Stewart an interview on The Daily Show in which he illuminated just how far his country had to go before reaching progress on par with US. He says,

We don't have, as institutions, left, right and center. Now, as Americans, especially this year, you know where you stand on health and taxes. For most Jordanians, they have no concept of what that means vis-à-vis left, right, and center. So, if you could understand that we're, we're so far at the start of this issue, where - how do Jordanians identify what it means to be left of center or right of center: So the next four years of...parliament and of where it comes into government, we, we're going to have to start. We have 30 odd political parties that I hope will come down to two, three, or four representatives - left, right, and center. So, that next four years, that's going to be a challenge (The Daily Show:September 25, 2012). 
Abdullah's interview deployed many of the same Orientalist tropes already familiar to most Westerners: Arabs, because of an inherent "tribal" mindset, are unfit to fashion a democratic political system by themselves and require the assistance of a Western-educated leader. He conjures a comparison to a political system based on the US model, which compartmentalizes ideological beliefs into distinctly "left, right, and center." Furthermore, in a post-9/11 world, modernity has come to be increasingly characterized by secularized society, free of religious extremists - particularly Islamic ones. Mindful of this, when asked by Stewart whether or not the Muslim Brotherhood had a presence in Jordan, the king responded that though the party was allowed participation in elections, it only represented a minute 12 percent of the political makeup -- making no mention of the results of the 1989 elections or the electoral laws which have followed since, ensuring the party's political underrepresentation. At the time of the interview, Jordan was just a few months shy of embarking upon parliamentary elections. Despite once again implementing illusory democratic reforms prior to the elections, such as allowing members of parliament, rather than the king, to appoint the prime minister and increasing the quota of women's seats from twelve to fifteen, the election was nevertheless proclaimed a fraud by the opposition and largely boycotted, not only by the IAF but also by other smaller political parties (Al-Jazeera 2013).

Nevertheless, throughout the interview, Abdullah maintained his diplomatic stance of peacemaking, reform, democratization, and his commitment to aiding his Western allies in maintaining regional stability. In the minds of most Westerners, that Jordan is an ally of the US and Israel is not an economic imperative deriving from the country's status as a semi-rentier state that relies heavily on international aid but an attestation to its commitment to being a leader in bringing the Arab world into the modern era of religious tolerance and moderation, a realm 
supposedly occupied by the above two nations. The truth of this matter was inconsequential, however, because this performance was not intended for a Jordanian audience but an American one. Like the tourism campaign analyzed previously, which sought to externally project Jordan's Bedouin history to the international community to legitimize its claim as a nation-state, the purpose of Abdullah's media campaigns is to externally project a representation of the state as a Westernized, moderate ally to the United States and Israel, accepting of political pluralism. The campaigns attempt to present a viable alternative trajectory for a state in the Arab world, a region supposedly fraught with sectarian conflict and Islamic fanaticism.

Regardless of the image of Jordan as synonymous with democracy and political and religious pluralism that Abdullah promoted externally, he nevertheless continued the Hashemite legacy of nurturing a particularistic, nativist identity among those East Bank origins internally. In light of the political and economic circumstances that Abdullah inherited from his father, new conflicts have erupted during his reign with which he has had to contend for the sake of regime security. The eruption of the second intifada in 2000 inflamed Transjordanian anxieties of another influx of Palestinian refugees into the state. Several years later in 2003, cognizant of the economic fallout that resulted from his father's refusal to back US interests in Iraq's invasion of Kuwait, Abdullah decisively came out in support of the US invasion of Iraq. Furthermore, between 750,000 to 1,000,000 Iraqi refugees fleeing the US occupation had sought refuge in Jordan, exacerbating unemployment rates and the scarcity of public resources. The state attempted to assuage Transjordanian citizens' anxieties by publicly referring to the transplanted Iraqis as "guests," emphasizing the refugees' temporary status in-country. The response formulated to address the regional instability in the midst of these events was Abdullah’s "Jordan First” (al-urdun awwalan) campaign in 2002. The nation-building initiative was an effort to 
place the country's domestic interests at the forefront of state policy and to internally stabilize a state unsettled by a deteriorating economy, the ongoing Israeli-Palestinian conflict, and the recent Iraq war. The thrust behind Jordan First aimed to "deepen the sense of national identity among citizens" while simultaneously "spread[ing] a culture of respect and tolerance to integrate and fortify a diverse, but united, national and social fabric.” Moreover, the endeavor fully embraced the neoliberalization policies first reluctantly undertaken by Hussein, striving to strengthen the private sector and building "a modern state through focusing on achieving economic, social, and political development, creating productive opportunities, fighting poverty and unemployment, and improving the living standards of all citizens” (emphasis added, Embassy of Jordan Website).

According to Fida J. Adely, “The 'Jordan First’ campaign fits distinctly into the regime’s historical efforts to construct a national identity through juxtaposition with other potentially threatening national identities, specifically a Palestinian one” (2012:64-65). Signs and billboards touting the slogan were erected across highway bridges and alongside busy roads. As part of the campaign, the state used the press as a mechanism by which to disseminate Transjordanian nationalistic sentiments. For the sake of national unity - which in practice prioritized a Transjordanian national unity loyal to the monarchy over a democratic, pluralistic one inclusive of other groups -- the majority of newspaper articles addressed specifically Transjordanian citizens' affairs and concerns (Al Oudat and Alshboul 2010:82), with relatively little space allotted for international affairs. The aim of this was to strengthen the Jordanian national consciousness by focusing on domestic issues of immediate concern; however, the disregard of regional issues outside of Jordan which nevertheless impacted the state - the invasion of Iraq, the stagnant Israeli-Palestinian peace process - continued to foment an ultra-nationalistic 
Transjordanian identity myopically concerned with their own affairs above those of other identity groups. While the state externally projected an image of itself "[creating] a favorable climate for the press and other media outlets to create a vibrant and transparent media environment” (Jordanian Embassy Website), as part of its continuing liberalization project, it was, in fact, tightening censorship around what could and could not be discussed publically. Additionally, the logic of Jordan First also purported that the “opposition's role should serve the causes and interests of the Jordanian people and strive to build Jordanian capacities, before defending other interests and objectives” (Al Oudat and Alshboul 2010:82). Translated into practice, this gave the government free reign to arrest political party activists and dissidents. Jordan First was a mechanism by which the government silenced oppositional voices; those who criticized the regime were labeled as “unpatriotic” and viewed as obstructing Jordan’s national unity project. In one instance, the state shut down an Al-Jazeera news station in Amman immediately after its broadcast of an interview with an American scholar critical of the monarchy (Al Oudat and Alshboul 2010:86). In this way, the regime has retained its monopoly of defining and redefining the parameters of Jordanian national identity by way of controlling the knowledge that citizens are allowed access. Through the lack of coverage of issues pertinent to Palestinians, Palestinian-Jordanians, Iraqi refugees, and the multiplicity of other groups outside the Transjordanians, the state continued to legitimize and make normative the nativist sentiments by only addressing their national concerns, just as it had in the aftermath of Black September.

Aside from the press, the Jordan First initiative also instrumentalized the educational system to promote its nationalistic aims. According to Adely, "Nationally, schools are the main conduits for state efforts to socialize young people as loyal citizens, as well as workers prepared to partake in the nation's development" and function as so in the context of Jordan as "the nature 
of Jordan's national identity and the legitimacy of the regime are challenged by demographic realities, economic crises, and regional conflicts” (2012:20). Just as textbooks pre-1967 elided the existence of an aspiring Palestinian national identity within Jordan through emphasizing a shared pan-Arab, pan-Islamic history (Nasser 2004), the post-Black September curriculum did so by focusing on the particularistic Bedouin narrative, structuring courses around Jordanian history (al-tareekh al-urdunee) and culture in general (al-thaqafa al-amma). Also, as many feminist anthropologists have argued, developmental discourses and policies place a particularized emphasis on women, often using their status within a Third World nation as an indicator of how far along that society has advanced along the Western-defined model of progress (see AbuLughod 2002; Abusharaf 2009; Adely 2012; Deeb 2006). Thus, the campaign focused on not only education, but the education of women in particular. For example, Adely's ethnographic fieldwork in the Al-Khatwa High School in Bawadi Al-Naseem - a primarily East Bank Jordanian area -- further elucidates how the Jordan First campaign was animated among the female student body. In addition to the aforementioned required Jordanian history and culture courses, the nationalization of the educational system included "slogans, daily rituals, and patriotic performances that were the substance of everyday interactions and celebrations of the nation” (2012:63). Such performances at the Al-Khatwa High School included a daily morning assembly (al-tabur) in which students raised a Jordanian flag while repeatedly chanting "Long Live Jordan,” followed by singing three consecutive songs meant to evoke a sense of national belonging: "Hail to the King," the Jordanian national anthem, and "My Homeland" (Mawatani) (2012:67), somewhat akin to the daily Pledge of Allegiance ritualized in the American school system. This daily ceremony was required by the Ministry of Education, and occasionally, supervisors from the ministry would make unannounced visits to the school to ensure that 
students were participating with the appropriate level of enthusiasm. On national holidays, the female students were called upon to take part in public national assemblies, singing patriotic songs, performing folk dances, and giving speeches declaring loyalty to the Jordanian state and the Hashemite monarchy, all the while dressed in "traditional" Bedouin clothing. This overt display of nationalism painted an image of authentic Jordan, as linked exclusively to a Bedouin history. So hegemonic was the Transjordanian narrative that Adely noted some students of Palestinian descent would go out of their way to assert their loyalties and avoid arousing suspicions, such as one Palestinian girl who prominently wore a "Jordan First" pendant around her neck daily (2012:62). Though one could argue that Palestinians have just as centrally played a formative role in Jordanian society and culture, no allusion to such was ever made at these gatherings. In this manner, these events continued the regime's tradition of creating a national unity by way of virtually erasing the Palestinian narrative. Furthermore, females played a central role in these assemblies, and Adely posits that these public displays "were consistent with the regime's efforts to create and display an image of 'modern' Jordan, one with a prominent role for women in its public life” (2012:71). The girls’ performances often served as prelude to the main speakers, who would enumerate the educational accomplishments achieved by the state within the year, including the number of schools that had been established, computer labs installed, teachers hired, and so forth (2012:72). These events functioned as a stage for the production and affirmation of Jordan's dual identity, at once celebrations of the nation's “traditional” Bedouin origins and as declarations of modernity. In the vein of the former, these performances continued the state's practice of equating Jordanian national belonging with a tribal, Bedouin identity - a banner under which East Bank Transjordanians could unite. Simultaneously, in the vein of the latter, the state's instrumentalization of females at the forefront of presenting this constructed 
national identity and the rhetoric of technological and educational advancement was a deliberate, self-conscious maneuver to present Jordan as in step with the neoliberal modernization project spearheaded by the West, in which women are the markers of modernity.

\section{Effects of the State's Economic Development Policies on the Local Populations}

In his study of global neoliberalism, Harvey suggests that the "[r]edistributive effects and increasing social inequality have in fact been such a persistent of neoliberalization as to be regarded as structural to the whole project” (2005:16), reconfiguring a new social strata in which economic power becomes concentrated in the hands of foreign investors, entrepreneurial elites, CEO's, and other leaders “that surround this inner sanctum of capitalist activity” (2005:33). Certainly, in the case of Jordan, Hussein and Abdullah's development and privatization measures have directly benefitted this upper echelon of individuals, while producing detrimental effects for those not as economically privileged, creating new economic fault lines which have served to both transcend and re-solidify social and political divisions.

One of the groups hardest hit by economic development are those Bedouins who still maintain a pastoral lifestyle. During the 1970's and 1980's, at the height of Jordan's tourism revitalization project and its valorization of the Bedouin as the "true" Jordanian, the government nevertheless embarked on several unsuccessful resettlement attempts of some of the indigenous tribes inhabiting the area, including the Bidul tribe living in Petra. Following its designation as a national park, the state perceived the tribe’s “flocks [as] destructive to Petra’s ancient ruins and a bother to the tourists" (Shoup 1985:283). Ironically then, while the state aimed to present the Bedouins as repositories of an "authentic" Jordanian culture to the Western gaze, it still wished to minimize contact between the local tribe and foreign tourists. The Bidul refused to comply 
with the resettlement plan, claiming lineage to the Nabateans and by extension, the right to live in Petra. In making this claim, the Bidul were consciously “differentiating themselves from modern Jordanian nationalists who claim Petra and the Nabateans for all Transjordanians” (Massad 2001:79), rejecting the narrow categorical parameters of nativist identity imposed upon them by the state. Despite their efforts, the state managed to relocate most of the families by 1984 into the settlement of Ayn Umm Sayhun. Furthermore, many Bedouin villages not displaced by the state have been bought by development organizations, such as Jordan Tourism Investments and the Noor al-Hussein Foundation, and subsequently transformed into hotels, resorts, and sites of training for the locals to work as staff in the hospitality industry (Shryock 2004:45-46). Women and young girls are especially sought out for employment within this sector, producing handicrafts for Western consumers interested in "traditional” souvenirs. In his ethnographic research in one such transformed village, Shryock posited, "None of the products made...is remotely traditional, but the people who make them are easily portrayed as traditional (if not altogether backward), and this certainly adds value” (2004:46). Once the villages are appropriated by the state, the locals are economically coerced into participating in a theater, performing the roles allocated to them by the tourism industry. At one of the transformed villages he visited, Shryock noted that upon entrance, the manager would introduce the local women working for him to the tourists, followed by an explanation of their tribal origins. The Bedouin women would then offer to the tourists a flatbread they had baked. This bread was not traditionally made by the tribe, nor did they take home any left over at the end of the day; it was made specifically for the foreign tourists, as a symbol of Jordanian hospitality (2004:46). In the same village, a foreign investor had planned to open a cafe, employing the local women to serve coffee to visiting tourists. This plan was met with resistance from patriarchs of the local tribe 
who were outraged at the thought of girls made to perform such a menial task traditionally reserved for servants and those of lower class standing. Consequently, the growing tourism industry and subsequent state interventions, such as the relocation of the Bidul and the conversion of tribal villages into tourist sites, have translated into the gradual planned obsolescence of the Bedouin pastoral economy. Thus, the individuals of these tribes have no other choice but to eke out a living participating in and reifying the commercialization their own culture; they cannot fully represent themselves but must take part in a state-sanctioned representation out of economic necessity. In this manner, the state imposes upon the Bidul a classificatory identity beyond their control but to which they must assimilate, making that representation and its consequences a material reality.

Aside from the aforementioned commercialization of these Bedouin hinterlands, the emerging economic adjustment measures first undertaken by Hussein and later furthered by his son Abdullah largely ignored the rural areas of the East Bank in favor of developing the urban areas of the northwest, including Amman and Irbid. As the government now largely neglected the farming and pastoralism once central to the state economy in favor of capitalist ventures, the uneven development produced a crippling level of poverty among the largely BedouinTransjordanian base in the East Bank hinterlands, an area once considered a bedrock of support for the Hashemite monarchy. This poverty was further aggravated by the lifting of subsidies and rolling back of social welfare programs that the state was forced to undertake in order to secure IMF and World Bank loans, resulting in "a new geography of popular protest...that seemed to reverse the polarities of Jordanian politics” (Tariq Tell, Abu-Rish interview pt. 1). In April of 1989, the increase of petrol prices as part of the new austerity measures sparked a series of protests in the southern rural areas, largely inhabited by tribes loyal to the monarchy. Their 
collective discontent was one of the events that precipitated the implementation of the SNTV electoral law; through this law, Hussein hoped to quell loyalists’ outrage through parliamentary overrepresentation. In 1996, the Jordanian government undertook its second economic restructuring program in collaboration with the IMF. As part of the program, Prime Minister Abdul Karim Kabarti lifted the nearly \$147 million subsidies on wheat products, once again devastating the already impoverished populations of the rural south. With the price of bread nearly doubling, citizens of these areas - most notably in the southern town of Karak - not only protested against the harsh austerity measures but also called for the resignation of Kabarti. The situation devolved into two straight days of rioting, and the state ultimately resorted to military force to suppress the demonstrations. King Hussein and Prime Minister Kabarti invoked the response typical of authoritarian regimes when confronted with internal populist uprisings, which was to deflect the blame from themselves onto external forces working to undermine the government -- in this case, Saddam Hussein and the Iraqi Ba’ath Party. In 2011, the Arab Spring, which spread across the Middle East, re-animated political protests in Jordan. These regular Friday demonstrations (al-hirak al-siyasi) significantly differ from the ones of 1989 and 1996 in that they have managed to unite Transjordanian nationalists, Islamic activists, and Marxist leftists and have additionally spread from the rural south to Irbid and Amman. They have taken on a character of social and economic justice, demanding the return of tribal territories seized by the state in the name of urban development, higher wages for workers, and restoration of laborers' rights lost through privatization (Tariq Tell, Abu-Rish interview pt. 2). When the government once again agreed in November of 2012 to lift fuel subsidies to secure a $\$ 2$ billion loan from the IMF, resulting in a 50 percent increase on cooking fuel, a 33 percent jump in heating gas, and a 14 percent spike in gasoline, activists again responded accordingly. The 
Bedouin-populated rural areas vociferously rioted against the lifting of the subsidies; demonstrators in the southern town of Ma’an, a critical site of the 1989 protests, obstructed traffic by burning tires. In the city of Irbid, demonstrators burned down a gas station in collective protest. In Amman, 2,000 protestors gathered in the main square (duwar al-dakhiliyya) to demonstrate in front of the Ministry of Interior. These demonstrations speak to an emerging class consciousness which is working to unsettle the once bounded Bedouin/not Bedouin or Transjordanian/Palestinian categories of identity prescribed by the state.

While the November 2012 and continual weekly protests demonstrate a pivot toward a more inclusive, social class consciousness which unifies Bedouins and Transjordanians with other non-indigenous identity groups, neoliberal policies of the regime have also conversely worked to re-strengthen nativist ideologies. In addition to further impoverishing and alienating the regime's primary foundation of political support, such economic restructuring measures brought on by the global modernization project to which the Jordanian state has capitulated has also fostered an ultra right-wing, nativist consciousness which is itself turning against the Hashemite monarchy. As middle-class Palestinians and Palestinian-Jordanian business elites comprise the majority of Jordan's private sector, this group of Transjordanians has witnessed the state's privatization policies directly benefitting this segment of the population, revitalizing an already nascent resentment. The conservatives' resentment is further inflamed by the number of foreign donors, NGO's, and international organizations devoted to elevating the status of Palestinian refugees in Jordan. While austerity measures continue to dictate the lifting of subsidies and the scaling back of social support programs, the right-wing East Bankers see their economic conditions worsening without the international intervention afforded to the Palestinians. Moreover, they perceive the current King Abdullah’s wife, Queen Rania, who was 
born in Kuwait to Palestinian refugees, and her work with local NGO's as furthering Palestinian interests in the country at their expense. Some of these conservative nationalists even suspect her of planning to establish a permanent alternative homeland for the Palestinians within Jordan. Curtis Ryan opines that, in the case of Jordan at least, "[the] Palestinians, long the base of the social pyramid, are perceived to be climbing to the top, while the Transjordanians feel the ground collapsing beneath their feet” (2010). Disenfranchised, these nationalists perceive the state as unfairly abandoning them in favor of a non-indigenous sector of the population. Aside from conceptualizing the Palestinians as an Other, these nationalists have also directed their resentment at those from Syrian, Iraqi, and Chechen backgrounds, and even gone as far as calling into question the "Jordanian-ness" of some Bedouin tribes (Massad 2001:273). As an extension of this ultra-nationalistic fervor, many of these conservatives advocate for an indigenous alternative to the Hashemite regime, one that would uphold the primacy of Transjordanian interests. Ironically, the nativist identity, which the Jordanian regime originally constructed and then nurtured over the course of nearly one hundred years, has also ultimately produced an opposition movement that threatens its very stability today.

\section{Conclusion}

Throughout this paper, I have argued that since its inception, the Jordanian government has consistently imported Western methods of modernization to cultivate a nativist identity to which the state could claim historical legitimacy, ultimately creating an authoritarian state and exclusivist polity and civil society inimical to Singer's idea of an inclusive, democratic "contractual nation," to which modernity aspires. Within this argument, I aimed to highlight the problematic imposition of a Western-driven modernization project, from colonialism, of which 
Jordan was originally conceived, to the neoliberal economic programs it has undertaken in the last thirty years. Following its inception as a nation-state in 1921, the regime imported from the British colonialists a military and legal infrastructure to incorporate the multiplicity of nomadic tribes into the political realm of the Jordanian nation-state. During this period, the regime began its practice of identifying which tribes it considered "Bedouin" -- an umbrella term under which the state placed a number of heterogeneous groups - and secured this new national identity through legal measures, such as the Bedouin Control Law of 1924. In 1948, following the creation of Israel, the Hashemites decided to expand its national identity from that of a particularistic Bedouin one into that of a pan-Arab, pan-Islamic one more inclusive of the resultant influx of Palestinian refugees into Jordan. However, following Black September, the regime contracted its discourse of national belonging, legitimizing the Bedouin-Transjordanian nationalists' claims to the state by way of media campaigns and awarding them even more positions within the civil bureaucracy. Settler-colonial expansion into the West Bank on the part of Israel a decade later prompted the state to launch its campaign of retroactively constructing a Bedouin historical genealogy to project on an international stage in order to obstruct Zionist aspirations of a Palestinian state within Jordan; this manifested in the heritage and tourism industries for the Western consumer. Meanwhile, regional politics and a looming economic crisis forced King Hussein into the neoliberal era, and his successor, Abdullah has continued these policies, deploying economic development, the façade of political liberalization, and the educational system to nurture the Bedouin-Transjordanian national consciousness that had long been synonymous with loyalty to the Hashemite regime. However, the regime could not contain the detrimental economic effects of its neoliberal structural adjustment programs on the Bedouin and Transjordanian populations, and it is now witnessing members of its once traditional bedrock 
of support joining opposition movements against the monarchy. While the effects of these economic policies have united some Transjordanians with Palestinian-Islamic activists, Marxists, and other dissidents of the monarchy, they have also fomented an ultra-nationalistic cohort of right-wing conservatives who wish to rid their state of non-indigenous elements, including the Hashemites themselves. In this way, we are currently observing the culminating, dichotomous effects of the Hashemites' nearly one hundred year-long campaign of “identifying," as well as two diverging potential avenues for a future Jordan: a cosmopolitan and truly democratic polity, inclusive of Palestinians, Syrians, Iraqis, Circassians, Chechens, and the multiplicity of other groups who reside within the nation or an increasingly exclusivist state based on an evercontracting notion of national identity. 


\section{Bibliography}

Abdullah II ibn Al-Hussein (King Abdullah II)

2012 Interview by Jon Stewart. The Daily Show with Jon Stewart. Comedy Central, September 25.

Abu-Lughod, Lila

1990 The Romance of Resistance: Tracing Transformations of Power Through Bedouin Women. American Ethnologist 17 (1):41-55.

Abu-Lughod, Lila 2002 Do Muslim Women Need Saving? Anthropological Reflections on Cultural Relativism and Its Others. American Anthropologist 104 (3):783-790.

Abu-Odeh, Adnan 1999 Jordanians, Palestinians and the Hashemite Kingdom in the Middle East Peace Process. Washington, DC: United States Institute of Peace Press.

Abu-Rish, Ziad 2012 Getting Past the Brink: Protests and the Possibilities of Change in Jordan, November 15: http://www.jadaliyya.com/pages/index/8375/getting-past-the-brink_protests-and-the-possibilit

Abu-Rish, Ziad

2012 Jordan's Current Political Opposition Movements and the Need for Further Research: An Interview with Tariq Tell (Part 2), August 24: http://www.jadaliyya.com/pages/index/7007/jordans-current-political-opposition-movementsand

Abu-Rish, Ziad 2012 On the Nature of the Hashemite Regime and Jordanian Politics: An Interview with Tariq Tell (Part 1), August 22: http://www.jadaliyya.com/pages/index/6979/on-the-nature-of-thehashemite-regime-and-jordania

Abusharaf, Rogaia Mustafa 2009 Transforming Displaced Women in Sudan: Politics and the Body in a Squatter Settlement. Chicago: The University of Chicago Press.

Adely, Fida J.

2012 Gendered Paradoxes: Educating Jordanian Women in Nation, Faith, and Progress. Chicago: The University of Chicago Press.

Adely, Fida J.

2012 When is Something, Something? Jordan's Arab Uprising, November 17: http://www.jadaliyya.com/pages/index/8451/when-is-something-somethingjordan\%E2\%80\%99s-arab-uprising 


\section{Al-Jazeera}

2013 Jordanians Vote in Parliamentary Polls, January 23:

http://www.aljazeera.com/news/middleeast/2013/01/201312312157574452.html

Al-Khalidi, Suleiman

2010 Tribalism Dominates Jordan’s Elections, November 9:

http://in.reuters.com/article/2010/11/09/idINIndia-52760920101109

Al Oudat, Mohammad Ali and Ayman Alshboul

2010 “Jordan First”: Tribalism, Nationalism and Legitimacy of Power in Jordan. Intellectual Discourse 18 (1):65-96.

Amawi, Abla

1992. Democracy Dilemmas in Jordan. Middle East Report 174:26-29.

Anderson, Benedict 2006[1983] Imagined Communities: Reflections on the Origin and Spread of Nationalism. New York: Verso.

Andoni, Lamis and Jillian Schwedler 1996 Bread Riots in Jordan. Middle East Report 201:40-12.

Bowker, Geoffrey C. and Susan Leigh Star

1999 Sorting Things Out: Classification and Its Consequences. Cambridge: The MIT Press.

Brand, Laurie 1995 Palestinians and Jordanians: A Crisis of Identity. Journal of Palestine Studies 24 (4): 4661.

Brubaker, Rogers and Frederick Cooper 2000 Beyond “Identity.” Theory and Society 29 (1):1-47.

Deeb, Lara 2006 An Enchanted Modern: Gender and Public Piety in Shi'i Lebanon. Princeton: Princeton University Press.

El-Shamayleh, Nisreen 2013 Understanding Jordan's Parliamentary Election, January 22: http://blogs.aljazeera.com/blog/middle-east/understanding-jordan\%E2\%80\%99sparliamentary-election

Embassy of Jordan Website http://www.jordanembassyus.org/new/aboutjordan/er1.shtml 
Fruchter-Ronen, Iris

2008 Black September: The 1970-71 Events and their Impact on the Formation of Jordanian National Identity. Civil Wars 10 (3):244-260.

Geertz, Clifford

1963 The Integrative Revolution: Primordial Sentiments and Civic Politics in the New States. In Old Societies and New States: The Quest for Modernity in Asia and Africa, edited by Clifford Geertz, pp. 105-157. Glencoe: The Free Press.

Geertz, Clifford

1971 After the Revolution: The Fate of Nationalism in New States. In Stability and Social Change. Bernard Barber and Alex Inkeles, eds. pp.357-376. Boston: Little, Brown and Company.

Greenwood, Scott 2003 Jordan’s “New Bargain:” The Political Economy of Regime Security. Middle East Journal 57 (2):248-268.

Harvey, David

2005 A Brief History of Neoliberalism. Oxford: Oxford University Press.

Howell, Sally

2003 Modernizing Mansaf: The Consuming Contexts of Jordan’s National Dish. Food and Foodways 11:215-243.

Kifah and Jennifer

2012 Jon Stewart's Theater of the Absurd, October 2:

http://www.jadaliyya.com/pages/index/7646/jon-stewarts-theater-of-the-absurd

Layne, Linda L.

1989 The Dialogics of Tribal Self-Representation in Jordan. American Ethnologist 16 (1):2439.

Layne, Linda L.

1994 Home and Homeland: The Dialogics of Tribal and National Identities in Jordan.

Princeton: Princeton University Press.

Lock, Margaret and Nancy Scheper-Hughes 1990 A Critical-Interpretive Approach in Medical Anthropology: Rituals and Routines of Discipline and Dissent. In Readings for a History of Anthropological Theory. Paul A. Erickson and Liam D. Murphy, eds. Pp. 530-555.

Massad, Joseph A. 2001 Colonial Effects: The Making of National Identity in Jordan. New York: Columbia University Press. 
Moore, Pete

2012 Why Not Jordan? November 13: http://www.merip.org/why-not-jordan

Murphy, Kim

2011 In Jordan, King Abdullah II Getting an Earful From Tribal Leaders, February 24:

http://articles.latimes.com/2011/feb/24/world/la-fg-jordan-tribes-20110225

Nanes, Stefanie

2008 Choice, Loyalty, and the Melting Pot: Citizenship and National Identity in Jordan.

Nationalism and Ethnic Politics 14:85-116.

Nasser, Riad

2004 Exclusion and the Making of Jordanian National Identity: An Analysis of School

Textbooks. Nationalism and Ethnic Politics 10:221-249.

The National

2010 In Jordan, One Man, One Vote, One Controversy, May 28:

http://www.thenational.ae/news/world/middle-east/in-jordan-one-man-one-vote-onecontroversy

Nevins, Edward and Theon Wright

1969 World Without Time: The Bedouin. New York: The John Day Company.

RT.com

2012 Jordan Bursts Into Protests Over Fuel Price Hikes, November 14:

http://rt.com/news/jordan-price-hike-protests-636/

Ryan, Curtis R.

1998 Peace, Bread and Riots: Jordan and The International Monetary Fund. Middle East Policy 6 (2):54-66.

Ryan, Curtis R.

2010 “We Are All Jordan”...But Who Is We? July 13:

http://www.merip.org/mero/mero071310

Shihab-Eldin, Ahmed

2008 Jordan First: A King's Modernization Motto Obscures a Palestinian Past and an Iraqi

Present, December 5: http://www.huffingtonpost.com/ahmed-shihabeldin/jordan-first-a-kingsmode_b_148589.html

Shoup, John

1985 The Impact of Tourism on the Bedouin of Petra. Middle East Journal 39 (2):277-291.

Shryock, Andrew

2004 The New Jordanian Hospitality: House, Host, and Guest in the Culture of Public Display. Comparative Studies in Society and History 46 (1):35-62. 
Shryock, Andrew

1995 Popular Genealogical Nationalism: History Writing and Identity among the Balqa Tribes of Jordan 37 (2):325-357.

Shryock, Andrew and Sally Howell

2001 "Ever a Guest in Our House”: The Emir Abdullah, Shaykh Majid al-Adwan, and the Practice of Jordanian House Politics, as Remembered by Umm Sultan, the Widow of Majid. International Journal of Middle East Studies 33 (2):247-269.

\section{Singer, Brian CJ}

1996 Cultural versus Contractual Nations: Rethinking Their Opposition. History and Theory 35 (3):309-337.

Wiktorowicz, Quinton 1999 The Limits of Democracy in the Middle East: The Case of Jordan. Middle East Journal 53 (4):606-620.

Yaghi, Mohammad

2012 Jordan's Election Law: Reform or Perish? October 4:

http://www.washingtoninstitute.org/policy-analysis/view/jordans-election-law-reform-orperish 